\title{
THE LOCAL VALUE OF BADONCEK FOR POLITENESS ASPECT IN MINANG COMMUNITIES WEST SUMATRA
}

\author{
${ }^{1 *}$ Muhammad Fauzi and ${ }^{2}$ Novita Sari \\ ${ }^{1,2}$ English Applied Linguistics, State University of Medan \\ *Corresponding author: fauzimhd88@gmail.com
}

\begin{abstract}
This study analysis talking about the local value of Communication is the important thing in humanities sociality. The main part of the sociality life. Nowadays, doing communication is strongly influenced by the culture when communication is stated. This paper discusses on the relationship politeness strategy and Minang culture in doing communication. The Minang here was limited in the badoncek from wedding ceremony in Minang culture is a spontaneous social action and suitable with the needs of the moment. Indeed, the theory that used in politeness strategy was taken from Brown and Levinson theory. This theory was elaborated become four types of politeness strategy. They are bald on strategy, positive strategy, negative strategy, and off record strategy. The prior aim in this paper is to describe what types of politeness strategy that used in Minang wedding ceremony in their social life and to elaborate the types of politeness strategies applied by qualitative research.
\end{abstract}

Keywords: politeness strategy, Minang culture, the impact of badoncek

\section{Introduction}

Languages are humanity's most valuable cultural heritage. Each language provides a system of concepts which helps human beings to interpret reality. The complexity of reality is easier to understand through the diversity of language. Progress in understanding the complexity of reality is due, amongst other things, to the growing linguistic diversity that has characterized the human species.

Those techniques were applied to obtain the valid information and the meaning of events and behaviors comprehensively. The local values applied by the indigenous communities as the victims of natural in some regions of West Sumatra include "Badoncek" tradition in Nagari Tandikat Padang Pariaman.

In badoncek master of ceremony is the key to make the event success. But for the research the writer will focus for the way of the master ceremony make badoncek is done. How the community gives something in badoncek and the master ceremony responds. For it the master ceremony gives the respond after the human of community less giving or much more. And the writer makes the classification positive or negative politeness. 
Proceedings of the $1^{\text {st }}$ Annual International Conference on Language and Literature, 18-19 April 2018, Fakultas Sastra, UISU, Medan, Indonesia.

\section{Literature Review}

Schiffman, H. F (1995) says about Indonesia;

1. Many languages are being existed for each culture from Sabang Island until Marauke Island.

2. Minang kabau is one of the cultures in Indonesia and has a language for human self.

The community leaders as explained in the following excerpts of interview: "Technically, badoncek is a spontaneous social action and suitable with the needs of the moment. Community is spontaneously involved in the action initiated by local leaders with certain propaganda such as the need to help victims of landslides for example. On behalf of the public interest, public figures have started to socialize through the medium to gather citizens, mosques and others but it is also applied in a stable condition such as when community build public facilities including roads, mosques and other public facilities. In fact, this tradition is also used when one of the residents hold weddings and any other events. Badoncek culture at its core has a deep meaning in the traditional Minang kabau philosophy. The essence of life shows that human beings do not live in their own life, but they need to help each other and they should lend a hand to help social interest (Navis, 1984). Besides, badoncek not only socially sustains public activities, but it is more oriented to counter countries limitations in overcoming the public affairs, especially from the financial side.

\section{Research Method}

This research design is research and politeness aspect. According to Arikunto (2002: 14), data source is the subject from which the data are obtained. The subject of this research is directed at the search data to the language maintenance of community of minang used qualitative researches. Collecting data inqualitativeresearchis done directly bythe researcher through observation, interview, in this research; the researcher only uses two of the kind techniques of collecting data. They are observation and interview for badoncek in wedding ceremony especially the language of master ceremony in minang culture.

\section{Discussion}

The data are collected in the form of words in order to give more understanding the researcher does not reduce the page upon page of narration. The researchers analyze the data with all of the richness as closely as possible to the form. According to Arikunto (2002: 14), data source is the subject from which the data are obtained. The subject of this research is directed at the search data to the language maintenance of master ceremony voice in badoncek used qualitative research. Then, the qualitative research is no random sample but purposive sampling of the statement by the video on the interview. Language is a communication tool. With language someone can communicate everything (Rayson, P., Leech, G. and Hodges, M, 1997).

The procedure of collecting data we will use Lincoln and Guba (1984), collecting data in qualitative research is done directly by the researcher through observation, interview, and assessment documentation. In this research, the researcher only uses 
two of the kind techniques of collecting data. They are observation and interview. The data are collected using video recording and was taken for about 5 minutes for every section. The video recording is then being transcribed and analyzed by using Brown and Levinson theory.

Politeness strategies are used to formulate messages in order to save the hearer's positive face when face-threatening acts are inevitable or desired. Brown and Levinson outline four main types of politeness strategies: bald on-record, negative politeness, positive politeness, and off-record (indirect) as well as simply not using the face-threatening act. The data of this study are the transcriptions of video recorded observation. The data was analyzed by identifying and classifying using the theory of politeness by Brown and Levinson and speech act theory.

Table 1. Politeness strategies summary chart

\begin{tabular}{|c|c|c|c|c|}
\hline \multicolumn{5}{|c|}{ Politeness strategies summary chart } \\
\hline $\begin{array}{r}\text { Politeness } \\
\text { strategy }\end{array}$ & Bald on-record & Positive politeness & Negative politeness & $\begin{array}{c}\text { Off-record } \\
\text { (indirect) }\end{array}$ \\
\hline Explanation & $\begin{array}{l}\text { Does nothing to } \\
\text { reduce the threat to } \\
\text { the hearer's face } \\
\text { and is therefore } \\
\text { used in close } \\
\text { relationships or } \\
\text { when information } \\
\text { needs to be shared } \\
\text { quickly. }\end{array}$ & $\begin{array}{l}\text { Is used as a way to } \\
\text { make the hearer feel } \\
\text { a sense of closeness } \\
\text { and belonging. }\end{array}$ & $\begin{array}{l}\text { Is used as a way to interact } \\
\text { with the hearer in a non- } \\
\text { imposing way. }\end{array}$ & $\begin{array}{l}\text { Is used to } \\
\text { completely } \\
\text { remove the } \\
\text { speaker from } \\
\text { any potential } \\
\text { to impose on } \\
\text { the hearer and } \\
\text { only alludes to } \\
\text { the speaker's } \\
\text { idea or specific } \\
\text { request. }\end{array}$ \\
\hline $\begin{array}{c}\text { Situation of } \\
\text { use }\end{array}$ & $\begin{array}{l}\text { - Urgency or } \\
\text { desperation } \\
\text { - When efficiency is } \\
\text { necessary } \\
\text { - Task-oriented } \\
\text { - Little or no desire } \\
\text { to maintain } \\
\text { someone's face } \\
\text { - Doing the face- } \\
\text { threatening act is } \\
\text { in the interest of } \\
\text { the hearer } \\
\text { - Situations where } \\
\text { the threat is } \\
\text { minimized } \\
\text { implicitly } \\
\text { - Welcomes } \\
\text { - Offers }\end{array}$ & $\begin{array}{l}\text { - Attend to the } \\
\text { hearer's interests, } \\
\text { needs, wants } \\
\text { - Use solidarity in- } \\
\text { group identity } \\
\text { markers } \\
\text { - Be optimistic } \\
\text { - Include both } \\
\text { speaker (S) and } \\
\text { hearer (H) in } \\
\text { activity } \\
\text { - Offer or promise } \\
\text { - Exaggerate } \\
\text { interest in H and } \\
\text { his interests } \\
\text { - Avoid } \\
\text { Disagreement } \\
\text { - Joke }\end{array}$ & $\begin{array}{l}\text { - Be indirect } \\
\text { - Use hedges or questions } \\
\text { - Be pessimistic } \\
\text { - Minimize the imposition } \\
\text { - Use obviating structures, } \\
\text { like nominalizations, } \\
\text { passives, } \\
\text { - or statements of general } \\
\text { rules } \\
\text { - Apologetic } \\
\text { - Use plural pronouns }\end{array}$ & $\begin{array}{l}\text { - Relies on } \\
\text { implication }\end{array}$ \\
\hline $\begin{array}{c}\text { Use } \\
\text { examples }\end{array}$ & $\begin{array}{l}\text { - Watch out! } \\
\text { - Hear me out... } \\
\text { - Pass me the } \\
\text { hammer } \\
\text { - Don't forget to } \\
\text { clean the blinds! } \\
\text { - Your headlights } \\
\text { are on! }\end{array}$ & $\begin{array}{l}\text { - You look sad. Can I } \\
\text { do anything? } \\
\text { - Heh, mate, can } \\
\text { you lend me a } \\
\text { dollar? } \\
\text { - I'll just come } \\
\text { along, if you don't } \\
\text { mind. }\end{array}$ & $\begin{array}{l}\text { - Would you know where } \\
\text { Oxford Street is? } \\
\text { - Perhaps, he might have } \\
\text { taken it, maybe. } \\
\text { - Could you please pass the } \\
\text { rice? } \\
\text { - You couldn't find your } \\
\text { way to lending me a }\end{array}$ & $\begin{array}{l}\text { - Wow, it's } \\
\text { getting cold } \\
\text { in here. }\end{array}$ \\
\hline
\end{tabular}


Proceedings of the $1^{\text {st }}$ Annual International Conference on Language and Literature, 18-19 April 2018, Fakultas Sastra, UISU, Medan, Indonesia.

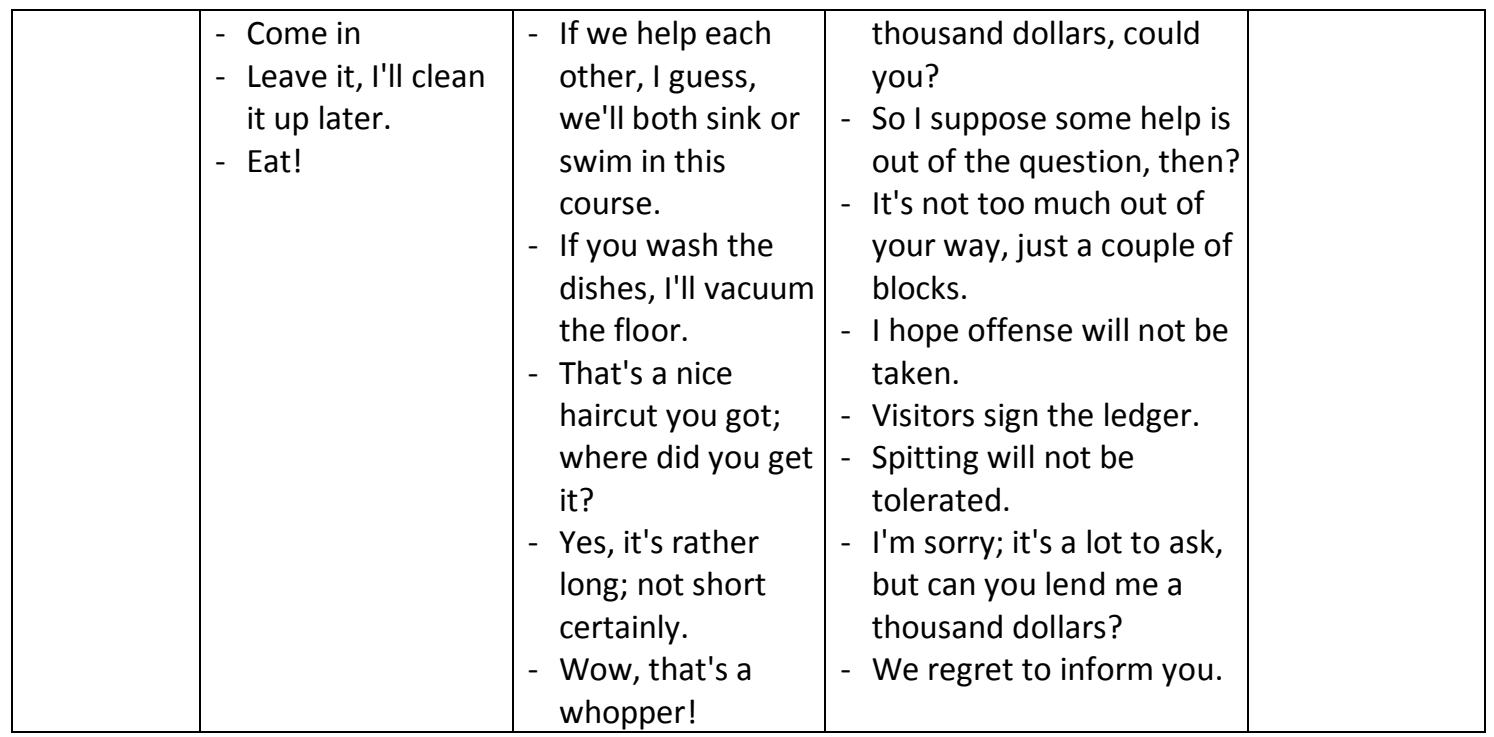

This strategy is most often utilized in situations where the speaker has a close relationship with the listener, such as Badoncek in wedding ceremony. Politeness strategies are used to formulate messages in order to save the hearer's positive face when face-threatening acts are inevitable or desired. Damage to the hearer the following is cases in which the positive face of the hearer (the person being spoken to) is threatened. An action that express from the speaker's assessment to the hearer's getting positive face or an element of his/her positive face. The speaker can display this disapproval in two ways. The first approach is for the speaker to directly or indirectly indicate that he dislikes some aspect of the hearer's possessions, desires, or personal attributes. The second approach is for the speaker to express disapproval by stating or implying that the hearer is wrong, irrational, or misguided. Examples: expressions of disapproval (e.g. insults, accusations, complaints), contradictions, disagreements, or challenges. Then the data was analyzed based on speech acts to consider its context. The analysis is shown in the following table.

Table 2. Data Analysis using Speech Acts

\begin{tabular}{|l|c|c|c|}
\hline \multicolumn{1}{|c|}{ Speech Acts } & $\begin{array}{c}\text { Showing Good } \\
\text { Manner }\end{array}$ & Not Showing Good Manner \\
\cline { 3 - 4 } & & Normative & Impolite \\
\hline $\begin{array}{l}\text { Criticizing / compliment: } \\
\text { 1. Dari sutan Maharudin sikumbang muko } \\
\text { belakang. Apa kanak daro. Rp 1.000.000. }\end{array}$ & & $\mathrm{V}$ & \\
\hline $\begin{array}{l}\text { Warning: } \\
\text { 1. Ulang alia } \\
\text { Kepada sanak mamak tuan sapangka, bar aka } \\
\text { digenapkan sadah aloe. }\end{array}$ & $\mathrm{V}$ & $\mathrm{V}$ & \\
\hline $\begin{array}{l}\text { Agreement: } \\
\text { 1. Ulang alia } \\
\text { Dari sutan maharudin sikumbang Rp. } \\
\text { 100.000 }\end{array}$ & $\mathrm{V}$ & \\
\hline $\begin{array}{l}\text { Advising: } \\
\text { 1. Iko dari mamak anak anak daro, lai } \\
\text { manunggu ko apa kanadaro siding } \\
\text { sapangka. }\end{array}$ & $\mathrm{V}$ & $\mathrm{V}$ & \\
\hline
\end{tabular}


There are some kinds politeness strategy which can be used by the speakers depending on what aspect of face is threatened. And for this section the writer will make correlation of the master ceremony speech act above with the analysis below:

- Bald on Record, speaker directly address the other as means of expressing our needs.

- Negative Politeness, orients to preserving the negative face of other people.

- Positive Politeness, orients to preserving the positive face of other people.

- Off Record (Indirect), removes the speaker from the potential to be imposing.

Table 3. The Dominant Types of Politeness used by master ceremony.

\begin{tabular}{|c|l|c|c|}
\hline No. & \multicolumn{1}{|c|}{ Types of Politeness Strategies } & Number & Percentage \\
\hline 1. & Positive Politeness & 17 & $60.3 \%$ \\
\hline 2. & Negative Politeness & 0 & 0 \\
\hline 3. & Bald on Record & 12 & $35.6 \%$ \\
\hline 4. & Off Record Total & 1 & $3 \%$ \\
\hline & \multicolumn{2}{r|}{30} & $100 \%$ \\
\hline
\end{tabular}

Based on the data analysis, it can be seen that master ceremony of wedding in Minang is polite. It is proven by the used of politeness strategy which are mostly used by badoncek process. As stated by Brown and Levinson (1987) that positive politeness orients to preserving the positive face of other people. This strategy emphasizes affiliation, closeness, or empathy, it indicates to shortening the distance. It indicates that master ceremony wants to build intimate situation between speaker and listener interaction in the wedding ceremony and the other event for Minang culture. But in the table, we can give more polite statement and never ask or give the normative statement to the guest or hearer. Positive politeness strategies can also emerge in situations where the speakers do not know each other well. For example, Charlotte Rees and Lynn Knight have explored the role politeness theory plays in general practice consultations. They found that, in an effort to remain polite, patients agreed to the presence of a listener observer during a general practice consultation even when the patient preferred a private consultation. Rees and Knight concluded that politeness strategies in the medical field can inhibit patients from providing complete and accurate information. Another use of positive politeness is polite or formal speech such as a type of formal speech can be used to protect the hearer's positive face.

\section{Conclusion}

Based on the research result, it concluded from Brown and Levinson' theory (1987) defines politeness as a set of strategies that people use in communication in order to minimize, avoid, or mitigate FTA toward the listener. In line with its theory of Brown and Levinson get the result.

1. This paper has discussed master ceremony in badonce of Minang wedding ceremony. The result discovers that master ceremony can be categorized as polite, shown by the strategies of politeness they used in the social solidarity in-group identity markers process.

2. That wedding ceremony is a place of the interaction process which happens between a master ceremony and a quest. It must be effective and polite. If in the wedding ceremony interaction runs well, the knowledge that will be delivered by the master ceremony will be received by listeners well. 
Proceedings of the $1^{\text {st }}$ Annual International Conference on Language and Literature, 18-19 April 2018, Fakultas Sastra, UISU, Medan, Indonesia.

\section{References}

Arikunto, S. (2002: 14). Prosedur Penelitian. Jakarta: Rineka Cipta.

Brown \& Levinson. (1987). Politeness: Some Universals in Language Usage. New york: Cambridge University Press.

Ida B. K. (1989). Penetuan Sample Metode Penelitian Survey, Jakarta LP3ES Mantra.

Lincoln \& Guba. (1985). Naturalistic Inquiry. Volume 75 Sage Focus Editions.

Navis, (1984). Alam Takambang Jadi Guru: Adat dan Kebudayan Minang Kabau. Graffiti Press. Jakarta.

Rayson, P., Leech, G. and Hodges, (1997). Languageis a communication tool. Lancaster University. UK.

Schiffman, H. F. (1995). Progress in understanding the complexity of reality human species. 